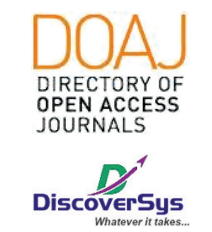

Published by DiscoverSys

\section{Hubungan Rasio Neutrofil Limfosit (RNL) terhadap kejadian relaps pada anak dengan sindrom nefrotik di RSUP Sanglah, Bali, Indonesia}

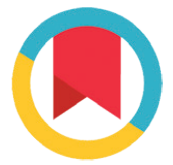

CrossMark

\author{
Wega Upendra Sindhughosa, ${ }^{1 *}$ Gusti Ayu Putu Nilawati, ${ }^{2}$ Ni Putu Siadi Purniti, ${ }^{2}$ \\ Bagus Ngurah Putu Arhana, ${ }^{2}$ Ketut Ariawati, ${ }^{2}$ Putu Junara Putra ${ }^{2}$
}

\title{
ABSTRACT
}

Background: Nephrotic Syndrome is a disease whose cause is not fully known and has a high relapse rate. The lymphocyte neutrophil ratio is a marker of inflammation in patients with malignancy, infection, and coronary heart disease. This study aims to determine the relationship between Neutrophil Lymphocyte Ratio (NLR) and the occurrence of relapse nephrotic syndrome.

Methods: This study was a retrospective analytic observational study with a cross-sectional approach to finding the relationship between increased NLR and the incidence of relapse in patients with nephrotic syndrome at SMF Children's Health Sciences Faculty of Medicine Universitas Udayana/Sanglah General Hospital. Data were taken from medical records of 45 respondents with episodes of relapse or remission from January 2018-January 2019. Data were analyzed using SPSS version 20 for Windows.
Results: The results showed that most of the subjects were male (71.1\%), aged 1-5 years (51.2\%), and aged $4.00 \pm 8.50$ years in both the relapse and remission groups. However, the infection rate (66.7\%) and medication adherence (75.0\%) tended to be higher in the relapse group. The analysis of the ROC curve shows the cut-off point of NLR was 2.36 (AUC: 0.521 ), with a sensitivity of $71.1 \%$ and a specificity of $73.3 \%$. There was a significant relationship between the NLR value and the incidence of relapsed nephrotic syndrome in multivariate analysis (adjusted OR: 4.53; 95\% Cl: 1.68 - 12.22; $p=0.003)$.

Conclusion: This study shows that there is a relationship between an increase in RNL and the incidence of relapse in pediatric nephrotic syndrome patients at Sanglah General Hospital, Bali, Indonesia.

Keywords: Child, Relapse Nephrotic Syndrome, Neutrophil Lymphocyte Ratio.

Cite This Article: Sindhughosa, W.U., Nilawati, G.A.P., Purniti, N.P.S., Arhana, B.N.P., Ariawati, K., Putra, P.J. 2020. Hubungan Rasio Neutrofil Limfosit (RNL) terhadap kejadian relaps pada anak dengan sindrom nefrotik di RSUP Sanglah, Bali, Indonesia. Intisari Sains Medis 11(2): $691-696$. DOl: 10.15562/ism.v11i2.652

\section{ABSTRAK}

Latar belakang: Sindrom Nefrotik merupakan salah satu penyakit yang penyebabnya belum sepenuhnya diketahui dan memiliki angka relaps yang tinggi. rasio neutrofil limfosit merupakan suatu pertanda inflamasi pada pasien yang mengalami keganasan, infeksi dan penyakit jantung koroner. Penelitian ini bertujuan untuk mengetahui hubungan Rasio Neutrofil Limfosit (RNL) dengan terjadinya sindrom nefrotik relaps.

Metode: Penelitian inimerupakan penelitian retrospektig observasional analitik dengan pendekatan potong lintang untuk mencari hubungan peningkatan RNL terhadap kejadian relaps pada pasien sindrom nefrotik di SMF IImu Kesehatan Anak FK UNUD/Rumah Sakit Umum Pusat Sanglah. Data diambil dari rekam medik terhadap 45 responden dengan episode relaps maupun remisi dari Januari 2018-Januari 2019. Data dianalisis dengan SPSS versi 20 untuk Windows.
Hasil: Hasil penelitian menunjukkan bahwa sebagian besar subyek adalah laki-laki $(71,1 \%)$, berusia 1-5 tahun $(51,2 \%)$, maupun berusia $4,00 \pm 8,50$ tahun baik pada kelompok relaps maupun remisi. Akan tetapi angka infeksi $(66,7 \%)$ maupun ketidak patuhan pengobatan $(75,0 \%)$ cenderung lebih tinggi pada kelompok relaps. Analisa kurva ROC menunjukkan titik potong RNL sebesar 2,36 (AUC: 0,521) dengan sensitivitas $71,1 \%$ dan spesifisitas $73,3 \%$. Terdapat hubungan bermakna antara nilai RNL dengan kejadian sindrom nefrotik relaps pada analisis multivariat (adjusted OR: 4,53; 95\%IK: 1,68 - 12,22; $p=0,003$ ).

Simpulan: Penelitian ini menunjukkan bahwa terdapat hubungan antara peningkatan RNL terhadap kejadian relaps pada penderita sindrom nefrotik anak di RSUP Sanglah, Bali, Indonesia 


\section{PENDAHULUAN}

Sindrom Nefrotik pada anak merupakan penyakit glomerulopati yang paling sering ditemukan pada anak, merupakan suatu kumpulan gejala-gejala klinis yang terdiri dari proteinuria masif, hipoalbuminemia, hiperkolesterolemia serta edema. ${ }^{1}$ Sindrom Nefrotik merupakan salah satu penyakit yang harus mendapat perhatian, karena penyebabnya belum sepenuhnya diketahui dan memiliki tatalaksana yang belum sepenuhnya optimal., ${ }^{1,2}$ Sebagian besar penderita akan mengalami sindrom nefrotik relaps sering, dependen steroid, atau resisten steroid. ${ }^{2}$ Penyebab dari Sindrom Nefrotik dibagi menjadi 3 yaitu kongenital, primer/idiopatik, dan sekunder mengikuti penyakit sistemik. Sampai pertengahan abad ke-20 morbiditas sindrom nefrotik pada anak masih tinggi yaitu melebihi 50\% sedangkan angka mortalitas mencapai $23 \% .^{3}$

Mortalitas dan prognosis anak dengan sindrom nefrotik bervariasi berdasarkan etiologi, berat, luas kerusakan ginjal, usia anak, kondisi yang mendasari dan responnya terhadap pengobatan. ${ }^{4}$ Insidens Sindrom Nefrotik pada anak dalam kepustakaan di Amerika Serikat dan Inggris adalah 2-7 kasus baru per 100.000 anak per tahun, dengan prevalens berkisar 12-16 kasus per 100.000 anak. $^{5}$ di Negara berkembang insidensnya lebih tinggi. Angka kejadian sindrom nefrotik pada beberapa negara dilaporkan mencapai 6 per 100.000 per tahun pada anak berusia kurang dari 14 tahun dimana perbandingan anak laki-laki dan perempuan sebesar 2:1. ${ }^{6}$

Nilai Rasio Neutrofil Limfosit (RNL) sebagai penanda adanya inflamasi memiliki beberapa keunggulan diantaranya tidak dipengaruhi oleh kondisi seperti aktivitas dan penanganan in vitro spesimen darah yang dapat memengaruhi nilai absolut dari subtipe leukosit, kemudian rasio neutrofil limfosit merupakan penanda inflamasi yang menggambarkan penggabungan dua proses imunitas yang berbeda kedalam satu pemeriksaan. ${ }^{7}$ Neutrofil merupakan leukosit granular matur polimorfonuklear yang berperan dalam inflamasi nonspesifik yang akan mengeluarkan mediator inflamasi seperti elastase, myeloperoksidase dan radikal bebas oksigen yang berperan dalam proses inflamasi, sedangkan limfosit memiliki peranan sebagai sistem imun spesifik dimana semakin rendah nilai limfosit semakin berat terjadinya stress fisiologis pada tubuh. ${ }^{7}$ Oleh karena itu neutrofil limfosit rasio memiliki sifat lebih prediktif dibandingkan tiap subtipe leukosit itu sendiri. ${ }^{7}$

Pada pasien sindrom nefrotik terjadi proteinuria. Proteinuria yang masif dapat menyebabkan terjadinya renal tubulointerstitial inflamation..$^{8}$ Studi sebelumnya di laboratorium menunjukkan protein seperti albumin dan transferin dapat menstimulasi sel tubulus proksimal untuk membentuk kemokin seperti monocyte chemoattractant protein-1 (MCP1) yang merekrut monosit, sel $T$, interleukin-8 yang menarik neutrofil. ${ }^{8}$

Berkaitan dengan pemaparan di atas, penelitian ini bertujuan untuk mengetahui hubungan antara Rasio Neutrofil Limfosit (RNL) dengan kejadian relaps pada pasien sindrom nefrotik di RSUP Sanglah, Bali, Indonesia.

\section{METODE}

Penelitian ini merupakan penelitian observasional analitik retrospektif dengan pendekatan potong lintang dimana mengambil data dari rekam medik untuk mencari hubungan peningkatan rasio neutrofil limfosit pada pasien sindrom nefrotik relaps di SMF Ilmu Kesehatan Anak FK UNUD/ Rumah Sakit Umum Pusat Sanglah dan mengambil data rekam medik dari Januari 2018-Januari 2019.

Populasi Target adalah semua anak usia 0 sampai 18 tahun dengan Sindrom nefrotik. Populasi Terjangkau adalah semua anak usia 0 sampai 18 tahun dengan Sindrom Nefrotik di ruang rawat inap dan yang datang berobat ke poliklinik Departemen/KSM Ilmu Kesehatan Anak FK UNUD/Rumah Sakit Umum Pusat Sanglah. Kriteria inklusi penelitian ini adalah anak usia 0 sampai 18 tahun yang telah didiagnosis sindrom nefrotik oleh dokter anak konsultan nefrologi. Anak dengan kelainan bawaan mayor, imunodefisiensi, gizi buruk dilakukan eksklusi.

Pemilihan sampel dari populasi terjangkau dengan cara non random sampling yaitu dengan consecutif sampling (secara berurutan). Subjek penelitian adalah sampel yang memenuhi kriteria inklusi dan ekslusi. Sampel ditentukan oleh peneliti. Instrumen pengumpulan data adalah form berisi identitas subyek penelitian, data anthropometri, rekam medik pemeriksaan darah lengkap dan hitung jenis leukosit, serta pemeriksaan urinalisis rutin pada pasien Sindrom nefrotik saat pasien baru terdiagnosis. Pengisian data anak dilakukan oleh peneliti.

Dilakukan pengumpulan data karakteristik dasar berupa nama, nomor rekam medis, usia, dan jenis kelamin, kepatuhan berobat, dan infeksi. Pengambilan darah lengkap (jumlah neutrofil dan limfosit) dan urinalisis diambil dari data rekam medic. Data untuk darah lengkap pembanding diperoleh dari pasien anak dengan diagnosis sindrom nefrotik pada evaluasi darah lengkap terakhir setelah pemeriksaan urinalisis ditemukan proteinuria kualitatif $\leq+1$. 
Dilakukan Analisis deskriptif dengan menggunakan SPSS versi 20.0 pada Windows untuk mengetahui gambaran data berdasarkan kelompok usia dan jenis kelamin. Data diolah dan dijelaskan dalam bentuk narasi, tabel, grafik. Nilai cut-off RNL ditentukan dengan cara melakukan plot dalam grafik Receiver Operating Curve untuk menilai cut-off dengan sensitivitas dan spesivisitas tertinggi untuk memprediksi status sindrom nefrotik. Setelah ditentukan cut-off dengan sensitivitas dan spesifisitas tertinggi maka variabel dianalisis sebagai variabel nominal dikotom berdasarkan cutoff ( $\leq$ cut off, >cut off). Analisis hubungan dilakukan untuk mengetahui hubungan antara variabel bebas dengan variabel tergantung. Variabel bebas dengan skala nominal dengan variabel tergantung dengan skala nominal dianalisis dengan uji ChiSquare dan rasio odd (Odds Ratio) dengan. Nilai $\mathrm{p} \leq 0,05$ dianggap bermakna pada penelitian ini.

\section{HASIL}

Berdasarkan data karakteristiknya, sampel pada studi ini didominasi oleh lelaki dengan persentase $71,1 \%$ sedangkan perempuan memiliki persentase $28,9 \%$. Usia pasien berada dalam rentang 1 tahun hingga 15 tahun dengan median usia $4 \pm 8,5$ tahun. Berdasarkan kelompok usia, kelompok usia terbanyak dalam sampel ini adalah 1-5 tahun dengan persentase $51,2 \%$. Persentase kelompok subjek episode relaps dan episode remisi dengan infeksi adalah masing-masing sebesar $66,7 \%$ dan $33,3 \%$.

Table 1 Karakteristik dasar responden penelitian

\begin{tabular}{lcc}
\hline & \multicolumn{2}{c}{ Frekuensi } \\
\cline { 2 - 3 } Variabel & Relaps (n=45) & Remisi (n=45) \\
\hline Jenis Kelamin, n (\%) & \\
Laki-Laki & $32(71,1)$ & $32(71,1)$ \\
Perempuan & $13(28,9)$ & $13(28,9)$ \\
Usia, n (\%) & $23(51,2)$ & $23(51,2)$ \\
$1-5$ tahun & $11(24,4)$ & $11(24,4)$ \\
$6-10$ tahun & $11(24,4)$ & $11(24,4)$ \\
$11-15$ tahun & $4 \pm 8,50$ & $4 \pm 8,50$ \\
Median Usia \pm IQR (Tahun) & & $16(33,3)$ \\
Infeksi, n (\%) & $32(66,7)$ & $29(69,0)$ \\
Infeksi & $13(31,0)$ & $37(63,8)$ \\
Tidak infeksi & & $8(25,0)$ \\
Kepatuhan, n (\%) & $21(36,2)$ & $2,35 \pm 1,22$ \\
Patuh & $24(75,0)$ & \\
Tidak patuh & $4,83 \pm 2,69$ & \\
Nilai RNL (rerata $\pm S B)$ & & \\
\hline
\end{tabular}

IQR: Interquartile-Range; SB: Simpang Baku
Pada kelompok episode relaps, tingkat kepatuhan mencapai 36,2\% dan pada kelompok episode remisi, tingkat kepatuhan sebesar 63,8\%. Sedangkan RNL pada kelompok relaps adalah 4,83 \pm 2.69 sedangkan pada kelompok remisi adalah 2,35 $\pm 1,22$ (Tabel 1).

Berdasarkan analisis kurva ROC, didapatkan titik potong RNL 2,36 (AUC: 0,521) dengan sensitivitas $71,1 \%$ dan spesifisitas $73,3 \%$; sehingga kadar $\mathrm{RNL}<2,36$ digolongkan sebagai RNL rendah dan kadar RNL > 2,36 digolongkan sebagai kadar RNL tinggi. Gambar kurva ROC dapat dilihat pada Gambar 1.

Data pengelompokkan nilai RNL dari hasil kurva ROC dianalisis lebih lanjut dengan uji chisquare (Tabel 2). Pada tabel didapatkan bahwa hasil kadar RNL yang tinggi $(>2,36)$ lebih banyak dimiliki oleh kelompok sindrom nefrotik relaps, yaitu sebesar $72,7 \%$. Sebaliknya, kadar RNL yang rendah $(<2,36)$ paling banyak dimiliki oleh kelompok sindrom nefrotik remisi $(71,7 \%)$. Dari data tersebut, disimpulkan bahwa kelompok RNL yang lebih tinggi berisiko mengalami sindrom nefrotik relaps sebesar 6,7 kali $(95 \% \mathrm{IK}=2,68-17,03 ; p<0,05)$ dibandingkan dengan RNL yang lebih rendah (Tabel 2). Kelompok infeksi lebih tinggi berisiko mengalami relaps sebesar 4,46 kali (95\%IK: 1,83$10,8 ; \mathrm{p}<0,05)$. Kelompok tidak patuh terhadap pengobatan berisiko lebih tinggi mengalami relaps sebesar 5,28 kali $(95 \% \mathrm{IK}=2,01-13,8 ; \mathrm{p}<0,05)$.

Analisis multivariat dengan regresi logistik dilakukan untuk mengetahui hubungan RNL, infeksi, dan kepatuhan berobat. Pada Tabel 3 dapat dilihat bahwa variabel yang memiliki hubungan secara bermakna terhadap sindrom nefrotik relaps yaitu rasio neutrofil-limfosit (adjusted OR 4,53;

\section{Roc Curve}

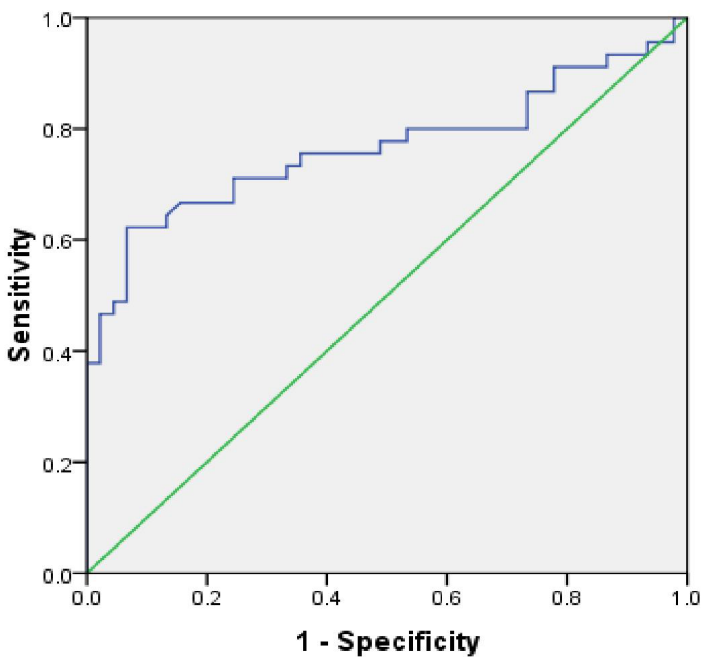

Gambar 1 Analisis ROC antara RNL dengan kelompok sindrom nefrotik relaps maupun remisi 
Tabel 2 Hubungan antara nilai RNL, infeksi, kepatuhan dengan kelompok remisi dan relaps pada sindrom nefrotik

\begin{tabular}{|c|c|c|c|c|c|}
\hline \multirow[b]{2}{*}{ Variabel } & \multicolumn{2}{|c|}{ Episode Sindrom Nefrotik } & \multirow[b]{2}{*}{$\mathbf{P}$} & \multirow[b]{2}{*}{ OR } & \multirow[b]{2}{*}{$95 \%$ IK } \\
\hline & Relaps ( $\mathrm{N}=45$ ) & Remisi ( $\mathrm{N}=45$ ) & & & \\
\hline \multicolumn{6}{|l|}{ Kategori RNL, n (\%) } \\
\hline Tinggi $(>2,36)$ & $32(72,7)$ & $12(27,3)$ & $<0,05$ & 6,76 & $2,68-17,03$ \\
\hline Rendah $(<2,36)$ & $13(28,3)$ & $33(71,7)$ & & & \\
\hline \multicolumn{6}{|c|}{ Kategori infeksi, n (\%) } \\
\hline Infeksi & $32(66,7)$ & $16(33,3)$ & $<0,05$ & 4,46 & $1,83-10,8$ \\
\hline Tidak infeksi & $13(31,0)$ & $29(69,0)$ & & & \\
\hline \multicolumn{6}{|c|}{ Kepatuhan berobat, n (\%) } \\
\hline Tidak patuh & $24(75,0)$ & $8(25,0)$ & $<0,05$ & 5,28 & $2,01-13,8$ \\
\hline Patuh & $21(36,2)$ & $37(63,8)$ & & & \\
\hline
\end{tabular}

OR: odds-ratio; IK: interval kepercayaan; Nilai P dikatakan bermakna apabila kurang dari 0,05

Tabel 3 Analisis multivariat regresi logistik hubungan RNL, infeksi, dan kepatuhan berobat

\begin{tabular}{lccc}
\hline Variabel & $\mathbf{P}$ & Exp (B) & $\mathbf{9 5 \% ~ I K ~}$ \\
\hline Infeksi & 0,086 & 2,42 & $0,88-6,67$ \\
Kepatuhan & 0,033 & 3,18 & $1,09-9,25$ \\
RNL & 0,003 & 4,53 & $1,68-12,22$ \\
\hline
\end{tabular}

95\% IK: 1,68-12,22; $\mathrm{p}<0,05)$, kepatuhan berobat (adjusted OR 3,18: 95\%IK: 1,09-9,25; $\mathrm{p}<0,05$ ) (Tabel 3).

\section{PEMBAHASAN}

Karakteristik pasien dengan sindrom nefrotik relaps dalam penelitian ini di dominasi oleh jenis kelamin lelaki dan kelompok usia 1-5 tahun. Hasil penelitian ini sesuai dengan penelitian yang dilakukan oleh. karakteristik pasien dengan relaps sindrom nefrotik didominasi oleh lelaki dengan rasio lelaki dibandingkan perempuan adalah 2:1 dan dominasi kelompok usia di 2-6 tahun. ${ }^{9}$

Untuk menganalisis hubungan nilai RNL dengan status relaps dan remisi pada sindrom nefrotik, titik potong yang tepat harus ditentukan dalam penelitian ini. Hasil analisa kurva ROC di pilih untuk menentukan titik potong RNL karena acuan nilai normal RNL pada populasi khusus seperti pediatri masih menjadi perdebatan pada penelitian-penelitian sebelumnya. Sebuah penelitian yang dilakukan di Eropa menemukan bahwa rentangan nilai normal RNL pada populasi dewasa adalah $0,78-3,53$ dengan rerata $1,65 .{ }^{10} \mathrm{Di}$ Indonesia belum terdapat data yang menunjukkan rentangan nilai normal RNL, terutama pada populasi anak, sehingga nilai 2,36 yang didapatkan dari analisa kurva ROC dan masih termasuk dalam rentangan dari penelitian sebelumnya diasumsikan dapat menjadi titik potong klasifikasi yang tepat dalam penelitian ini dengan nilai sensitivitas $71,1 \%$ dan spesifisitas $73,3 \%$.

Dalam penelitian ini ditemukan bahwa terdapat perbedaan rerata yang signifikan antara nilai RNL pada kelompok relaps dan remisi, dimana kelompok relaps memiliki nilai rerata yang lebih besar dibandingkan dengan kelompok remisi. Hasil analisa lebih lanjut dengan menggunakan titik potong 2,36 dari analisa kurva ROC juga menemukan bahwa kelompok relaps memiliki kecenderungan untuk memiliki nilai RNL yang lebih tinggi dibandingkan dengan kelompok remisi. Hasil penelitian ini menunjukkan bahwa peningkatan nilai RNL dapat dijadikan sebagai faktor prediktor kejadian relaps pada sindrom nefrotik.

Sebuah penelitian terdahulu pada tahun 2012 yang meneliti faktor prediktor relaps pada anak dengan sindrom nefrotik menemukan bahwa rerata hitung netrofil pada kelompok frekuen relaps lebih tinggi dibandingkan dengan infrekuen relaps sedangkan yang nampak pada hitung limfosit adalah kebalikannya dimana kelompok frekuen relaps lebih rendah dibandingkan dengan infrekuen relaps meskipun hasil tersebut tidak signifikan secara statistik. ${ }^{9}$ Hasil temuan tersebut secara tidak langsung menggambarkan kecenderungan rasio neutrofil banding limfosit lebih besar pada kelompok anak dengan relaps frekuen dibandingkan dengan relaps infrekuen. Penelitian lainnya yang meneliti kadar limfosit pada pasien dengan sindrom nefrotik menemukan bahwa kadar limfosit secara signifikan lebih rendah pada pasien sindrom nefrotik yang resisten terhadap kortikosteroid dibandingkan dengan yang sensitif. ${ }^{11}$ Hasil penelitian tersebut mendukung hasil penelitian ini, dikarenakan jumlah limfosit yang lebih rendah pada pasien sindrom nefrotik resisten steroid yang diasumsikan cenderung mengalami relaps memiliki hubungan terhadap lebih tingginya nilai RNL. Penelitian yang dilakukan oleh Bertelli et al 
juga meneliti kadar neutrofil pada pasien sindrom nefrotik secara tidak langsung melalui penilaian peningkatan produk Reactive Oxygen Species (ROS) dimana pada sindrom nefrotik relaps terjadi peningkatan ROS yang diproduksi neutrofil setidaknya $400-600 \%$ secara bermakna. ${ }^{12}$

RNL yang tinggi juga menunjukkan hubungan bermakna dengan rendahnya survival jangka panjang pada pasien nefropati idiopatik dimana nilai $\mathrm{RNL}>3,34$ memiliki risiko 3,3 kali lebih besar untuk memiliki tingkat survival jangka panjang lebih rendah dibandingkan dengan kadar RNL yang lebih rendah secara bermakna. ${ }^{13}$

Meskipun penelitian yang melihat RNL pada sindrom nefrotik masih sangat terbatas, nilai RNL sudah digunakan sebagai faktor prediktor dari penyakit ginjal lainnya. Sebuah penelitian yang dilakukan oleh Turkmen et.al menggunakan RNL untuk memprediksi proses inflamasi pada pasien gagal ginjal stadium akhir (ESRD) dan menemukan bahwa pasien dengan kadar RNL yang tinggi $(>3,5)$ memiliki kecenderungan peningkatan kadar sitokin penanda proses inflamasi seperti TNF- $\alpha$ secara signifikan dan didominasi oleh kelompok ESRD. ${ }^{14}$

Selain itu RNL juga dikaitkan dengan progresi penyakit ginjal kronik dimana peningkatan kadar RNL dihubungkan dengan kejadian protein uria pada pasien gagal ginjal kronik. Hal ini menunjukkan bahwa proses inflamasi memainkan peran dalam penurunan fungsi ginjal yang diperlihatkan dengan peningkatan proteinuria seperti pada penelitian sebelumnya. ${ }^{15}$

RNL digunakan sebagai faktor prediktor dari berbagai penyakit serta perkembangan berbagai penyakit yang dikaitkan dengan proses inflamasi. Tingginya kadar RNL pada pasien dengan relaps sindrom nefrotik dihubungkan dengan adanya peningkatan proses inflamasi akibat proses autoimun pada penyakit sindrom nefrotik. ${ }^{16}$ Produksi neutrofil di luar sumsum tulang belakang juga diregulasi oleh jaringan sitokin yang melibatkan berbagai interleukin (IL) seperti IL-17 yang memulai granulopoiesis dan G-CSF yang mengatur pelepasan neutrofil. Pada saat inflamasi, berbagai sitokin pro inflamasi dapat menstimulasi IL-17 dan G-CSF yang pada akhirnya meningkatkan kadar neutrofil. ${ }^{16}$ Bukti inflamasi pada sindrom nefrotik relaps telah diketahui sejak beberapa dekade yang lalu, dimana sebuah penelitian yang diterbitkan pada tahun 1995 sudah menunjukkan adanya peningkatan kadar sitokin pro-inflamasi seperti IL-8, IL-2, IL- 4 dan IFN- $\gamma$ pada pasien sindrom nefrotik relaps dibandingkan dengan pasien sindrom nefrotik remisi (30ng/ml vs $17 \mathrm{ng} / \mathrm{ml} ; 240 \mathrm{U} / \mathrm{mL}$ vs $8 \mathrm{U} / \mathrm{mL}$; $450 \mathrm{pg} / \mathrm{ml}$ vs $110 \mathrm{pg} / \mathrm{ml}$ dan $600 \mathrm{U} / \mathrm{ml}$ vs $300 \mathrm{U} / \mathrm{ml}$ $\mathrm{p}<0,05) .{ }^{17}$ Hasil penelitian ini mendukung logika antara peningkatan RNL pada pasien sindrom nefrotik relaps terkait dengan adanya peningkatan inflamasi pada sindrom nefrotik relaps secara linier maupun pada penyakit keganasan lainnya. ${ }^{17,18}$

Selain neutrofil, komponen RNL lainnya yaitu limfosit juga memiliki peranan dalam patofisiologi sindrom nefrotik. Peran sel limfosit yang dibuktikan dengan keefektifan terapi peningkat sel limfosit-B seperti rituximab. Peningkatan kadar limfosit seperti $\mathrm{TCD}^{+}{ }^{+} \mathrm{FoxP}^{+}$dapat meningkatkan efek imunosupresi khususnya pada penyakit dengan patofisiologi utama autoimun. Mereka bekerja dengan menghambat proliferasi, aktivasi dan produksi dari mediator inflamasi seperti TCD4+, TCD8+, NK, sel B, makrofag dan sel denditrik. ${ }^{11}$

\section{SIMPULAN}

Angka kejadian sindrom nefrotik relaps sebesar $62 \%$. Terdapat perbedaan nilai rerata rasio neutrofil-limfosit (RNL) pada kelompok relaps dan remisi. Terdapat hubungan rasio neutrofil limfosit dengan sindrom nefrotik relaps.

\section{KONFLIK KEPENTINGAN}

Tidak terdapat konflik kepentingan dalam penulisan laporan penelitian ini.

\section{ETIKA PENELITIAN}

Penelitian ini dilaksanakan berdasarkan kelaikan etik penelitian dari Komite Etik Fakultas Kedokteran Universitas Udayana/RSUP Sanglah Denpasar No.219/UN14.2.2.VII.14/LP/2019 dan surat ijin No. LB.02.01/XIV.2.2.1/32509/2019.

\section{PENDANAAN}

Penulis bertanggung jawab terhadap pendanaan penelitian ini tanpa melibatkan pihak sponsor, beasiswa, ataupun sumber pendanaan lainnya.

\section{KONTRIBUSI PENULIS}

Seluruh penulis memiliki kontribusi yang sama dalam penulisan laporan penelitian ini baik dari tahap penyusunan kerangka konsep, pengumpulan data penelitian, analisis data penelitian, hingga penyusunan laporan penelitian dalam bentuk publikasi.

\section{DAFTAR PUSTAKA}

1. Wang CS, Greenbaum LA. Nephrotic Syndrome. Pediatr Clin North Am. 2019;66(1):73-85.

2. McCloskey O, Maxwell AP. Diagnosis and management of nephrotic syndrome. Practitioner. 2017;261(1801):11-15. 
3. Pal A, Kaskel F. History of Nephrotic Syndrome and Evolution of its Treatment. Front Pediatr. 2016;4:56.

4. Wynn SR, Stickler GB, Burke EC. Long-term prognosis for children with nephrotic syndrome. Clin Pediatr (Phila). 1988;27(2):63-68.

5. Eddy AA, Symons JM. Nephrotic syndrome in childhood. Lancet. 2003;362(9384):629-639.

6. Mallick NP. Epidemiology and natural course of idiopathic nephrotic syndrome. Clin Nephrol. 1991;35 Suppl 1:S3-S7.

7. Akrimi JA, Al-Jashamy K, George LE, Suliman A, Ahmad AR. Frequency Rate of Abnormal Morphologic Shapes of The Erythrocytes upon the Different Types of Anemia. Int J Scient \& Eng Res. 2013;4(7):2476-2482.

8. Wang Y, Chen J, Chen L, Tay YC, Rangan GK, Harris DC. Induction of monocyte chemoattractant protein- 1 in proximal tubule cells by urinary protein. J Am Soc Nephrol. 1997;8(10):1537-1545.

9. Sarker MN, Islam MMSU, Saad T, SHoma FN, Sharmin LS, Khan HA, et al. Risk Factor for Relapse in Childhood Nephrotic Syndrome-A Hospital Based Retrospective Study. Faridpur Med Coll J. 2012;7(1):18-22.

10. Forget P, Khalifa C, Defour JP, Latinne D, Van Pel MC, De Kock M. What is the normal value of the neutrophil-tolymphocyte ratio?. BMC Res Notes. 2017;10(1):12.

11. Guimarães FTL, Ferreira RN, Brito-Melo GEA, RochaVieira E, Pereira WDF, Pinheiro SVB, et al. Pediatric Patients With Steroid-Sensitive Nephrotic Syndrome Have Higher Expression of T Regulatory Lymphocytes in Comparison to Steroid-Resistant Disease. Front Pediatr. 2019;7:114.

12. Bertelli R, Trivelli A, Magnasco A, Cioni M, Bodria M, Carrea A, et al. Failure of regulation results in an amplified oxidation burst by neutrophils in children with primary nephrotic syndrome. Clin Exp Immunol. 2010;161(1):151-158.
13. Tsai SF, Wu MJ, Chen CH. Low serum C3 level, high neutrophil-lymphocyte-ratio, and high plateletlymphocyte-ratio all predicted poor long-term renal survivals in biopsy-confirmed idiopathic membranous nephropathy. Sci Rep. 2019;9(1):6209.

14. Turkmen K, Guney I, Yerlikaya FH, Tonbul HZ. The relationship between neutrophil-to-lymphocyte ratio and inflammation in end-stage renal disease patients. Ren Fail. 2012;34(2):155-159.

15. Binnetoğlu E, Sengül E, Halhallı G, Dindar S, Sen H. Is neutrophil lymphocyte ratio an indicator for proteinuria in chronic kidney disease?. J Clin Lab Anal. 2014;28(6):487-492.

16. Rosales C. Neutrophil: A Cell with Many Roles in Inflammation or Several Cell Types?. Front Physiol. 2018;9:113.

17. Neuhaus TJ, Wadhwa M, Callard R, Barratt TM. Increased IL-2, IL-4 and interferon-gamma (IFN-gamma) in steroid-sensitive nephrotic syndrome. Clin Exp Immunol. 1995;100(3):475-479.

18. Prabawa IPY, Bhargah A, Liwang F, Tandio DA, Tandio AL, et al. Pretreatment Neutrophil-to-Lymphocyte ratio (NLR) and Platelet-to-Lymphocyte Ratio (PLR) as a Predictive Value of Hematological Markers in Cervical Cancer. Asian Pac J Cancer Prev. 2019;20(3):863-868.

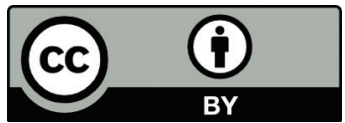

This work is licensed under a Creative Commons Attribution 